\title{
Musefication of the architectural legacy of Medieval Alania
}

\author{
Julia Treyman ${ }^{1, *}$ \\ ${ }^{1}$ Don State Technical University, pl. Gagarina, 1, Rostov-on-Don, 344010, Russia
}

\begin{abstract}
The article is devoted to the particularities of the process of musefication of the historic and cultural legacy of Medieval Alania, an integral part of natural landscapes of the North Caucasus. It turned up that the natural and spacial carcass of the North Depression pot hole was the particular scenario for the development of territorial and spacial organization of settlements. The carcass is also the basis for the development of the museum exposition. Museum and touristic routes can be created following ancient trade routes, along which the alans created their settlements. The alans animated the nature and created a network of sacred objects. It can be represented in the form of a carcass structure consisting of sacral objects (such as sacred mountains, trees, groves, springs, lakes, separate stones, caves etc.). The sacred objects and the routes to them formed sacred topography of Alania. They can be used as the centerpieces of the museum and tourist routes. The alani settlements situated along the roads can be the main elements of expositions. Revealing and preserving spacial structure and historic connections between the objects of the main exposition should be the basis of our conception of musefication of the historic and cultural landscape of Medieval Alania. This decision will let us demonstrate the unique objects of region's cultural legacy including the historic landscape in the best possible way.
\end{abstract}

\section{Introduction}

In the mountain and foothill regions of the North Caucasus there are territories with rich historic and cultural legacy, which is the material incarnation of the culture of medieval Alania and a vivid reminder of the byzantine Christian culture that used to exist in this region in the tenth century. In the Middle Ages the region was the center of Christian culture of the North Caucasus due to multiple contacts between the eastern and the European cultures on the Silk road. Numerous trade routes and a continuous network of medieval settlements along these routes support our point of view.

The ethnic groups that inhabited the North Caucasus since the ancient period ( the zygii (the circassians), the alans, nakh peoples, the svans, the tsez people, the pannonian avars etc.), the ethnic groups of Dagestan, the dvals, the Iberians (the Georgians, the Abkhazians) had similarities in their world view paradigms based on the mythological way

* Corresponding author: juliatreyman@gmail.com 
of thinking, conservatism, existence of strong patronymic structures, the cult of ancestors and mutual relations built on unwritten laws and customs. The culture of medieval Alania is one of the local variations of folklife cultures of the Caucasus characterized by similarity and stability of traditions that were displayed in organization of architectural and cultural field in the unique way.

The musefication of this ambience and its architectural elements casts light on the medieval history of the region; it will make it clearer and more intelligible for the modern society because in this particular case architecture acts as a documentary source.

\section{Development of a museum exposition}

According to G. V. Esaulov one of the possible ways of the musefication of architectural objects is the creation of historic and cultural memorial estates and open-air museums basing on the preserved historic parts of local settlements and scientifically reasoned addition of full-size maquettes built of proper materials. The second way is to convert complex architectural monuments such as the surviving parts of villages and settlements into memorial estates. In this case particular objects of architectural and cultural importance such as towers, fort walls, sections of ancient roads, sanctuaries, temples, cult buildings and sacral memorial objects should also be made museums. In certain cases it is possible to recreate their interiors and crate ethnographical expositions [1]. The top-priority decision in this case is one that allows us to completely preserve the historic ambient and reveal positional and historic connection between the elements of the exposition.

The habitat of the alans was formed within certain boundaries due to the influence of the nature and landscape. Mountain and foothill territories are full of cloughs and water gaps (the Bolshaya Laba, the Urup, the Kyafar, The Bolshoy Zelenchuk, the Maliy Zelenchuk, the Kuban, the Teberda) along which the majority of the Alani settlements are situated. Through these ravines run the north Caucasian routes of the Silk road, mountain roads connecting the settlements and providing territorial and social unity and the systematic character of Alani displacement. The above mentioned ravines pierce in the north-east direction the part of the North Depression pot hole from the passes of the Great Range and the Side Range in the south to the passes of the Rocky Range in the north and thus connect mountain and foothill regions and define the particular spacial carcass and the character of Alani displacement.

The natural and spacial carcass of the North Depression pot hole acts as the scenario for the development of the scheme of territorial and spacial organization of the settlements and is the basis for the development of the exposition. We can highlight several parts of natural and spacial structure of the North Depression intermountain pot hole and cross-border mountain regions:

- the Rocky Range that lies between mountain and foothill regions. This range is the northern border of the pot hole and the western part of Alania;

- the part of the pot hole between the ranges which is the complex of ravines divided by watershed ranges;

- the Side Range which is parallel to the Main Caucasus Range. It forms the southern border of the pot hole and the western part of Alania.

The above mentioned ranges acted as natural barriers and defense perimeter protecting the pot hole against invaders. The only weak not naturally protected regions were ravines' jaws used for communication between the settlements. The ravines were defended all the way from the ranges to the plain. The existing natural and spacial situation influenced the location of main fortresses of Alania, which were like gates in the ranges (the Side one and the Rocky one) used to control and defend the jaws. Thus the displacement of the alans was strongly influenced by the natural and spacial structure of the pot hole naturally protected 
by the mountain ranges. Nowadays we can create touristic routes following ancient roads connecting the settlements of the alans. The alans animated the nature and created a network of sacred object. It can be represented in the form of a carcass structure consisting of sacral objects (such as sacred mountains, trees, groves, springs, lakes, separate stones, caves etc.), marked in the space and base ways of reaching them (roads, streets and mountain routes). These sacral objects were image-bearing symbolic centerpieces organizing the living space within some limited territory. The borders of the territory under the aegis of the sacral objects could be formed by visibility or the limits of influence of a patronymy (the manor of a patronymic family or a patronymic settlement), natural and landscape boundaries (a mountain range, an off spur, a ridge or a highland). The base routes had non-rectilinear irrational (at first sight) character. It may be explained by the importance of emotional perception of this way towards a sacral object and the surrounding landscape. The sacred objects and the routes to them formed sacral topography of Alania. These sacred objects are worshiped even today. They can be used as centerpieces in the structure of museum and tourists routes.

Spacial expression of traditional culture of the alans together with alani-byzantine intercultural blends, which existed in the X-XII centuries influenced the development of the particularities of architectural and spacial organization of the settlements. Basing on the conducted research we can enumerate two main types of settlements: traditional and blended settlements. The traditional type of settlements has a three-part planning pattern characterized by: linear arrangement of all the parts along one axis, in a strict order: the citadel, the fortress, the fortified settlement; vertical compositional development of the planning pattern; the geometrical center had no meaning for the city-planning composition of a settlement. The citadel was the symbolic center of a settlement, it was identified with the center of the universe, situated on the edge of the world. That is why it was usually situated on the edge of a mountain in its highest part so that the fortress and the fortified settlement were in front of it, symbolizing the image of the front world full of light; behind it was the abyss representing the idea of the back world full of danger and uncertainty. The fact that a settlement was situated on the mountain also has its symbolic meaning because a mountain is the natural and spacial representation of the World tree, which in the Caucasian mythology, links all the worlds and corresponds to the vertical axis of the universe. Thu a mountain situated on the ground and reaching the skies connects the three parts of the mythological model of the world (the underground, the ground and the skies); and linearly situated three levels of a settlement symbolize the mythological model of the universe. All the three parts of a settlement are connected by the main street which might me the spacial representation of the mythological axis of the universe. The majority of alani settlements situated along the trade routes (including the residence of the tsar on Mount Spire (the Kyafar settlement)) have a similar structure. Revealing and preserving the peculiarities of the spacial and planning structure of the settlements must be made a priority when developing an open air museum exposition.

The settlements of medieval Alania can be the object of a museum exposition. All the settlements can be divided in two groups: those with the traditional planning pattern and those of the blended type. The best example of the first group is the Kyafar settlement. On its territory the researchers have found more than 200 stone buildings which give a comprehensive idea of the settlement's planning pattern. Also it is one of the biggest settlements of medieval Alania. According to the researchers the residence of Alani governor of the XI c. Durgulel the Great was situated here [2].This settlement consists of three parts: the Uptown settlement, the Downtown settlement and the onshore unfortified settlement. [3]. The Uptown and Downtown parts are situated on Mount Spire which has a narrow and oblongated form and stretches for $1,5 \mathrm{~km}$. along the river Kyafara. The main street coincides with the axis of the mountain and runs through the whole city. On its way 
there are open spaces such as squares surrounded by abutting buildings. The territory of the settlement is characterized by the gradually increasing altitude difference conditioned by the fact that the slope reaches its maximum point on the south-west edge of the mountain.

In the most utmost and the highest part of the mountain there is a complex of 14 buildings grouped around an empty space that forms the inner court in which we can find the basement of a mono-apsis church. This territory is surrounded by steeps except for the north-west direction. The access to this area is possible only from north-west through a gate formed in a split of a mountain to which leads the main street. According to V. A. Kuznetsov the above mentioned buildings on the top of the mountain are the residence of Alani governor of the XI c. Durgulel the Great [2]. The area of the residence is $80 \times 50 \mathrm{~m}$. According to its planning structure and its topographical location in the highest point of the relief, this territory could represent the citadel of the settlement and be the symbolic center of the settlement.

Outside the territory of the residence we can find a part of the settlement represented by abutting building stretching for $900 \mathrm{~m}$. along both sides of the main street. In the north-east this territory is separated from the Downtown settlement by the defensive wall combined with a rocky body which crosses the mountain edgeways and in which the gates are situated. It is possible that this part of the settlement and its buildings were the fortress which housed the tsar's army.

The Downtown part of the settlement is poorly preserved. Among the discovered buildings are the perimeters of several buildings, a natural sanctuary on a residual mountain and a defensive wall with gates running along the north-east naturally unprotected border of the settlement. The unprotected onshore settlement lying along Mount Spire on the shore of the river Kyafar has not preserved. Nowadays there are fruit gardens in this place. Judging by its location it was a separately situated settlement that appeared near the bigger and fortified settlement.

By the mid X century in Alania alongside with the traditional type the blended type of settlements was created. It appeared as a result of alani-byzantine intercultural contacts and blends and represented in its planning pattern both the traditional features and the features of byzantine culture. Among the traditional features of this type are:

- the configuration of the settlement's planning influenced by the natural form of the occupied territory (the form of the plateau, the river valley etc.);

- three-part planning pattern of a settlement;

- the shift of the symbolic center away from the geometrical center of the city architectural composition;

- linear development of the planning pattern of a settlement;

- patronymic system of displacement in the special organization of the living area.

The features of the blended planning structure differentiating it from the traditional type are:

- in the architectural and city-planning composition appear symbolic centerpieces represented by Christian temples that were located according to the principles of byzantine Christian topography;

- in the planning pattern appear the center of the city represented by a square with a temple to which runs the main street;

- in the planning pattern appear major streets. Their directions emerged into the main street which led to the centre of the settlement [4].

The capital of medieval Alania, the Nizhne-Arkhyzskoe settlement had the planning structure of this type. The settlement was situated in a river valley on the right shore of the river Big Zelenchuk. The main part of the built-up area including the defensive works lies in the featureless part of the valley and is defined by its configuration. The extended structure of the settlement was formed along the river valley and stretched for $3 \mathrm{~km}$. The 
three major streets of the settlement are curvilineal and correspond to the curves of the natural landscape. The defensive works are created with due regard to the peculiarities of the relief and cross the valley edgeways, in a naturally unprotected direction forming four defensive lines. In the planning structure of the settlement we can distinguish the territory of the city itself and the territory of Alani metropole lying outside the city and separated from it by a field. In the city-planning composition of the city it is possible to mark several buildings representing the symbolic and presentative centerpieces and become the centers of the built-up area with all the main routes leading to them. These centerpieces are the sanctuary of a circular form, the Southern Temple and the Middle Temple. The above listed buildings create a single architectural and spacial ensemble which forms the ideological and social center of the city in which the three main streets meet.

The territory of the Alani metropole is 800 meters northeastward form the urban area. V. A. Kuznetsov notes that such a distance between a city and a metropole can be also found in the planning patterns of Byzantine cities in the VIII-IX centuries for example in the city of Sardis [5]. It was connected with the city by the only road formed by the mergence of the three major streets. The northern temple is a symbolic center of metropole's architectural ensemble and the metropolitan cathedral of Alania. The territory of the metropole had a well-developed structure and occupied the area of 6,4 ha. The majority of the buildings are situated on the plain territory. Among them are the residence of the Alani metropolitan, a monastery complex, three mono-apsis churches and a Christian graveyard. These buildings and the adjacent area were surrounded by a stone wall. This complex in whole represented the center of the Alani metropole and had some features of a fortress. North-eastward form it there was a Christian burial complex that consisted of three chapels within a Christian graveyard and stone hedges. Two other Christian complexes were situated on mount "Three pines" and mount "Church". All the above listed objects are connected by ancient roads. It is possible that an agricultural are lying southward also belonged to the territory of the Alani metropole. Necropoles situated on both shores of the Big Zelenchuk on the slopes surrounding the valley and facing the settlement were an important part of it.

Many researchers note that the settlement of Nizhne-Archizskoe was the outpost of byzantine influence in Alania [6], and its planning structure was formed during the period when Christian and byzantine cultures were spreading in the western region of the Alani kingdom in the X-XII centuries. [7] Christian temples and settlements built following the byzantine model [8] and located in space according to byzantine and Christian canons were the symbolic and presentative centerpieces and had major impact on the development of the planning pattern of a settlement which differed from the traditional one.

\section{Conclusion}

We need to mention that nowadays this area is world famous thanks to the ancient Christian shines that were situated here and became a target of pilgrimage. In the past ancient Christian temples were the symbolic and compositional centrepieces. But nowadays it is not clear because the special structure is covered by more recent historic stratums and the special links between the objects are badly damaged. That is why revealing and preserving the spacial and planning structure and historic links between the objects of the main museum exposition should be made the basis of the musefication conception of historic and cultural landscapes of medieval Alania. This decision will let us demonstrate the unique objects of region's cultural legacy including the historic landscape in the best possible way.

When developing the structure of the museum exposition we should turn the settlements of Nizhne-Archizskoe and Kyafar into one museum architectural and cultural ensemble and make them the center of the exposition because the cultural and ideological center of 
medieval Alania was situated here. These settlements are situated within walking distance in the neighboring ravines and are connected by an ancient road. Now we can connect them by creating a walking or horse-riding route between them. The main museum infrastructure should be developed on the territory of Nizhne-Archizskoe settlement. We should create museum and tourist routs starting in the center of the exposition and corresponding to the main ancient roads that formed the northern Caucasian part of the Silk road. The main objects of the exposition will be the Alani settlements situated along these roads. Each settlement is a unique architectural and archeological complex in the historic and natural landscape.

When developing projects of musefication of the architectural and archeological monuments of the region the following recommendation should be taken into account:

- conservation with the maximal degree of preserving of the exterior of an object that it had before the restoration should be made a priority;

- creation of a museum based on an archeological monument (object) should be gradual;

- the exposition should be projected in a way that allows to percept it as a single ambience, understand the connection between the main exposition and the open-air exposition (or the museficated object).

We need to drag the museficated architectural and archeological monuments into tourist activity in an active manner (to create museum and tourist complexes based on archeological reserves, organize scientific-tourist programs to preserve and popularize archeologic monuments), to promote closer interaction between architects, archaeologists, museum personnel, restorers and community when creating new museums. Taking these statements into account it is possible to create popular and, at the same time, informationpacked museum expositions based on architectural and archeological complexes. Musefication of architectural and archeological monuments (certain objects) is the most efficient way of their preserving for future generations. In these conditions they become an important part of historic and cultural legacy, that has an educational and creative meaning, promotes the creation of a tolerate society, capable of accepting and understanding other cultures in the correct manner.

The degree of success of the process of musefication of architectural and archeological monuments also depends on the harmony of the interaction between the specialists: architects-restorers, historians-archaeologists, museum personnel and administrators. Basing only on the principles of the priority of conservation with the maximal preservation of the exterior before the restoration, the gradual character of creation of a museum based on an architectural and archeological monument, projecting the exposition in the form of a single ambience showing the links between the main exposition, the open-air exposition and the landscape, it is possible to realize a productive activity in the sphere of the musefication of this type of objects of historic and cultural legacy. Thus the museficated architectural and archeological monuments can become the basis for the promotion of new forms of museum activity. Unique historic and cultural territories and ecomuseums can be made on their basis. The analysis of the statistical data from architectural and archeological memorial estates and museums that possess architectural and archeological objects shows that the process of preserving and actualization of this type of cultural legacy thought its musefication is still going on.

\section{References}

1. G.V. Esaulov, The architectural and urban legacy of the South of Russia: the formation of cultural potential. (NIITAG, Moscow 2004) 
2. V.A. Kuznetsov, Durgulel Great and the Nizhny Arkhyz. The research methodology and interpretation of archaeological materials of the Northern Caucasus. (Ordjhonikidze, 1988)

3. I.A. Arzhantseva, Z.H. Albegova, The cult stones in the Kyafar settlement (again about religious dualism Alan). Antiquities of the North Caucasus. (Moscow, 1999)

4. V.V. Pishchulina, S.D. Sulimenko, J.F. Treyman, The civil architecture of the North Caucasus of the X-XVII centuries. (Rostov-on-Don, 2014)

5. G.L. Kurbatov, G.E. Lebedeva, The city and the state in Byzantium in the era of transition from antiquity to feudalism. The city and the state in ancient societies. (Leningrad,1982)

6. V.A. Kuznetsov, Nizhny Arkhyz in the X-XII centuries To the history of medieval cities in the North Caucasus. (Stavropol: Kavkazskiy library, 1993)

7. V.V. Pishchulina, The Christian Church architecture of the North Caucasus in VIXVI centuries. Rostov-on-Don, (2012)

8. L.A. Perfilieva, The question of Byzantine influence on the religious architecture of North-West Caucasus of the X-XI centuries the Alans: Western Europe and Byzantium. (Ordjhonikidze: Iriston, 1992) 